Andrzej NIEWCZAS ${ }^{1}$, Łukasz MÓRAWSKI ${ }^{1}$, Ewa DĘBICKA ${ }^{1}$, Joanna RYMARZ ${ }^{2}$

${ }^{1}$ Motor Transport Institute (Instytut Transportu Samochodowego)

${ }^{2}$ Lublin University of Technology (Politechnika Lubelska)

\title{
PREDICTING COSTS OF CITY BUSES' INCAPACITY RISK
}

\section{Prognozowanie kosztów ryzyka niezdatności autobusów miejskich}

\begin{abstract}
The paper describes operational efficiency research of city buses from two manufacturers during the 6 years of operation under real conditions. The presented operational efficiency assessment model includes unplanned incidental repairs costs, downtime costs, as well as the likelihood of losing customer-passenger's trust. The results of the efficiency calculations were used to estimate the expected costs of buses' incapacity risk. It has been demonstrated that the operational efficiency and incapacity risk costs can be a criterion for the optimal period of operation, as well as the criterion of comparison of bus makes in a transport company.
\end{abstract}

Keywords: reliability, public transport, operational efficiency

Streszczenie: W pracy opisano badania efektywności eksploatacyjnej autobusów miejskich dwóch producentów $w$ czasie sześciu lat użytkowania $w$ warunkach rzeczywistych. Prezentowany model oceny efektywności uwzględnia koszty napraw nieplanowanych, koszty przestojów, a także prawdopodobieństwo utraty zaufania klienta-pasażera. Wyniki obliczeń efektywności wykorzystano do oszacowania przewidywanych kosztów ryzyka niezdatności autobusów. Wykazano, że efektywność eksploatacyjna i koszty ryzyka niezdatności moga stanowić kryterium optymalnego okresu eksploatacji, jak również kryterium porównania marek autobusów w przedsiębiorstwie transportowym.

Słowa kluczowe: niezawodność, transport publiczny, efektywność eksploatacyjna 


\section{Introduction}

Along with the development of urban agglomerations, the requirements and expectations of residents in relation to the city's infrastructure, also increase. This development leads to increase the living standards of the inhabitants, but on the other hand to an increase in costs of living. The resultant effect of these phenomena is the so-called suburbanisation, or the migration of people from cities to suburban areas [3]. This leads to the separation of the "strict" city (centre), with the headquarters of the workplaces and the suburban area where the housing estates are located. In such an urbanization model, the functioning of well-coordinated public transport fulfilling high quality and quantity requirements of travellers, is of great significance. In quality terms these requirements are understood as high reliability of transport means, punctuality and safety of the transport. In quantity terms, it is first and foremost the right number of transport means, adequate to the extensive transport network.

In the situation of dynamic development of large urban agglomerations, it is a challenge to the urban transport companies, to expect high quality transport with acceptable investment and operating costs. The quality of transport performed is strongly dependent on the reliability of the vehicles used. The high level of reliability determines high operational efficiency and punctuality of transport as well as maintaining steady level of customers - passengers' confidence.

However, ensuring high reliability of vehicles and maintaining it in the planned period of operation is a difficult task. Therefore, each urban transport system should take into account business continuity safeguards related to the risk of the incapacity of the vehicles fleet owned. This risk is generated already at the stage of purchasing transport means. It is also the basis for predicting operating costs $[1,4,5]$.

In this article, using the proprietary operational efficiency evaluation model and a database of incidental defects and repairs from the period of 6 years in relation to the group of city buses of two makes - domestic and imported, the expected costs of their incapacity risk were determined. In addition to the costs of unplanned repairs, the costs of lost revenue during the forced buses' downtime, were also included in the calculations, as well as costs related to the probable risk of losing customer's confidence.

\section{The course of research}

The research used data collected at a selected public transport company operating in one of the largest cities in Poland. For comparative purposes, the focus 
was on buses of two manufacturers, which for the purposes of this article were marked as follows: D - domestic, I - imported. In order to meet the homogeneity conditions of the statistical test, the vehicles from one production lot of each make were used for the trials. Buses were operated under the same road and climatic conditions. Samples of 20 D buses and 22 in the case of the I manufacturer, were put into operation at a similar calendar time. The follow-up period was 72 months (6 years). During that time, buses carried out regular passenger transport serving in rotation the scheduled public transport routes [8].

In table 1 there are technical and operational indicators for buses of both makes, and in table 2 collective operational intensity indicators are presented. It was adopted, in accordance with the applicable legal regulations, that the annual depreciation of vehicles is $10 \%$ of the purchase price of the bus and is constant over the entire period of operation.

Table 1

\section{Essential technical and operational parameters of buses}

\begin{tabular}{||l|l|l||}
\hline Parameters & D & I \\
\hline General characteristics & \multicolumn{1}{|l||}{ two-axle, single-deck, low-floor } \\
\hline Type-approval category & M3 & \multicolumn{2}{|||}{} \\
\hline Class & \multicolumn{1}{|l||}{ I (city), MAXI (vehicles 10,5-13 m long) } \\
\hline Number of seats & 29 & 27 \\
\hline Number of standing places & 74 & 78 \\
\hline Engine type & \multicolumn{2}{|l||}{ compression ignition } \\
\hline Engine capacity $\left[\mathrm{cm}^{3}\right]$ & 9186 & 7201 \\
\hline Engine max. power $[\mathrm{kW}]$ & 188 & 210 \\
\hline Curb weight $[\mathrm{kg}]$ & 10900 & 10860 \\
\hline Permissible total weight $[\mathrm{kg}]$ & 18000 & \multicolumn{2}{||}{} \\
\hline Purchase cost [thousand of PLN] & 750 & 830 \\
\hline
\end{tabular}

\section{Operational intensity indicators $[8]$}

Table 2

\begin{tabular}{||l|l|l||}
\hline \hline Indicator & D & I \\
\hline Samples count [pieces] & 20 & 22 \\
\hline Test time n [months] & 72 & \multicolumn{2}{|||}{} \\
\hline Average mileage in the period & 438,30 & 417,94 \\
\hline Of 72 months [thousand of km] & 6,09 & 6,46 \\
\hline Average monthly mileage [thousand of km] & 75 & 83 \\
\hline Annual depreciation [thousand of PLN] & 6,25 & 6,92 \\
\hline
\end{tabular}


To calculate the operational efficiency, the proprietary modification of the operational efficiency model presented in [2] was used. The equation describing the model improved in this paper is expressed by the formula:

$$
W_{e}=\frac{1}{\left(\frac{N_{u}}{A_{z}}\right)+\left(1-K_{g}\right)+F\left(t_{k}\right)}
$$

where:

$N_{u}$ - cumulative cost of incidental repairs in the time interval $(0, \mathrm{tk})$,

$A_{z} \quad$ - amount of depreciation up to the moment tk,

$K_{g}$ - technical readiness coefficient in the k-the interval of operation, $F\left(t_{k}\right)$ - Weibull distribution of time till the first defect,

$t_{k} \quad$ - the upper end of the $\mathrm{k}$-th time interval of operation (k-th interval of operation).

The model assumes balancing the threshold (minimum) revenue and vehicle depreciation costs.

Weibull distribution used as a time distribution model till the first defect is described by the formula:

$$
F\left(t_{k}\right)=1-e^{-\left(\frac{t_{k}}{a}\right)^{b}}
$$

where:

a - scale parameter,

$\mathrm{b}$ - shape parameter.

The scale and shape parameters were calculated based on the defects register of the tested $\mathrm{D}$ and I make buses. The calculation results are given in table 3.

Table 3

\section{Durability distribution parameters of the tested buses [7]}

\begin{tabular}{||l|l|l|}
\hline Manufacturer & Scale $\boldsymbol{a}$ parameter & Shape $\boldsymbol{b}$ parameter \\
\hline $\mathrm{D}$ & $87,9 \times 10^{3}$ & 0,955 \\
\hline $\mathrm{I}$ & $80,5 \times 10^{3}$ & 0,819 \\
\hline
\end{tabular}

The above-mentioned equation of the operational efficiency indicator (1) allows to determine the costs of incapacity risk, the general formula of which is defined as follows: 


$$
K_{e}=N_{u}+R_{b}+R_{p}
$$

The components in formula (3) express the costs of risk related to maintaining the serviceability of the vehicle affected by the unscheduled repairs $-N_{u}$, costs of risk related to the loss of revenue during vehicle downtime in the operational period $t_{k}-R_{b}$, costs of the risk of losing customer - passenger's confidence caused by the vehicle's incapacity $-R_{p}$. The full equation (3) is expressed by the formula:

$$
K_{e}=\sum_{k=1}^{n} N_{u}\left(t_{k}\right)+\sum_{k=1}^{n}\left[\Delta A_{z}\left(1-K_{g}\left(t_{k}\right)\right)\right]+A_{z} * 0,2 F\left(t_{k}\right)
$$

where:

$N_{u}\left(t_{k}\right)$ - costs of unplanned repairs in the $k$-th interval of operation,

$\Delta A_{z}$ - depreciation amount calculated in conversion to the average monthly mileage of the bus,

$K_{g}\left(t_{k}\right)$ - technical readiness factor in the $k$-th interval of the operation.

The model does not take into account planned costs. In particular, the costs of fuel, urea costs (Adblue), costs of planned technical services, personnel costs, insurance costs, taxes, other material costs were not taken into account. The risk of the loss of confidence expressed as the last component of the sum in the equations (3) and (4) contains an additional factor of 0.2 , which assumes that only every fifth passenger $(20 \%)$ will give up public transport due to repeated incapacity of buses and resulting lack of punctuality of services [9].

\section{Research results}

The efficiency indicator $\mathrm{W}_{\mathrm{e}}$ calculated from the equation (1), depending on the operational mileage, is shown in fig. 1 . The calculations were made in relation to the average monthly mileage. The graph shows a progressive decrease in the efficiency indicator along with the increasing time of use for the buses of both makes. Considering the entire observation period, the average value of the indicator for the D make is 1.181, and for the I make it is at the level of 1.228.

In order to more accurately compare vehicle makes with each other, taking into account their operational wear and tear, the total observation period has been divided into two specific periods. In the first place into a warranty period ( $0-2$ years) and a post-warranty period (3-6 years) (fig. 2). The values of the efficiency indicator in these both periods are compared for both makes, in particular during the post-warranty period. It is important that after the warranty period, the average 
value of the efficiency indicator in the remaining period of operation is two times lower. A detailed analysis of the costs of unplanned repairs allows to conclude that a more appropriate division is the period of full operational usefulness (in short FOU) and limited operational usefulness (LOU) [6]. The table 4 shows time ranges of operation on a monthly basis, based on which the limits of FOU and LOU periods for both makes were defined.

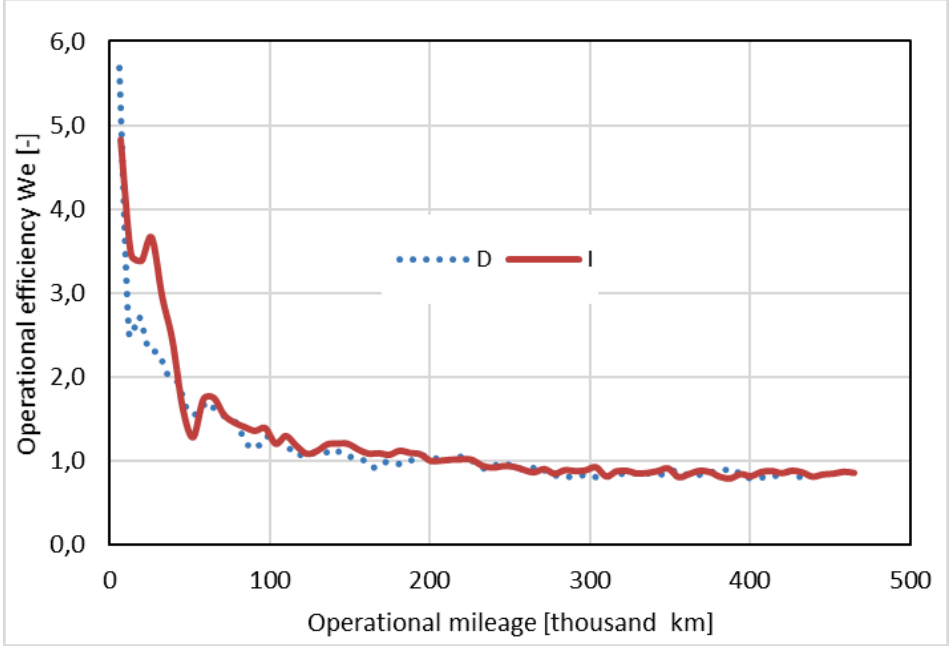

Fig. 1. Operational efficiency indicator $\mathrm{W}_{\mathrm{e}}$ as a function of the operating mileage for the total period of observation

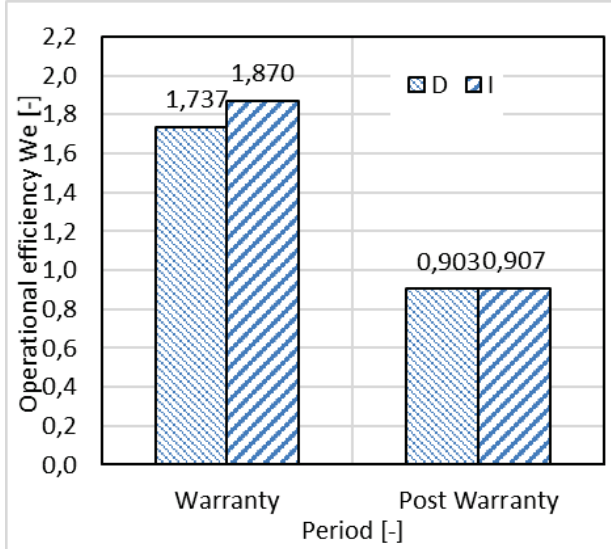

a)

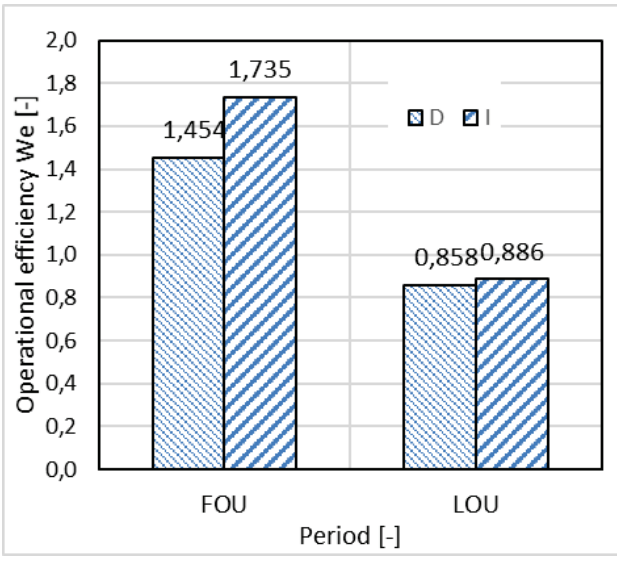

b)

Fig. 2. Average value of the operational efficiency indicator during the warranty and postwarranty period (a) and full operational usefulness and limited usefulness (b) 


\section{Table 4}

\section{Breakdown into FOU and LOU periods}

\begin{tabular}{|c|c|c|}
\hline Period & D & I \\
\hline FOU [mth] & $0-36$ & $0-29$ \\
\hline LOU [mth] & $37-72$ & $30-72$ \\
\hline
\end{tabular}

For FOU and LOU periods, statistical comparison of mean values using variance analysis method was carried out. The Shapiro-Wilk's and one-way variance analysis tests were used. The descriptive statistics are presented in table 5.

The structure of risk costs calculated according to the equation (5) for the D and I makes is presented in figures 3 and 4 . In order to increase clarity, additional lines were added with the auxiliary axis defining the percentage share of costs.

\section{Table 5}

The values of descriptive statistics of operational efficiency for both brands in different periods of bus use

\begin{tabular}{|l|l|l|l|l||}
\hline \multirow{2}{*}{ Period } & \multicolumn{4}{l|}{$\mathrm{D} / \mathrm{I}$} \\
\cline { 2 - 5 } & lower quartile & median & upper quartile & standard deviation \\
\hline Warranty & $1,151 / 1,201$ & $1,491 / 1,394$ & $1,960 / 1,923$ & $0,954 / 1,002$ \\
\hline Post-warranty & $0,836 / 0,85$ & $0,880 / 0,877$ & $0,972 / 0,936$ & $0,081 / 0,087$ \\
\hline FOU & $0,823 / 1,132$ & $1,101 / 1,294$ & $0,307 / 1,731$ & $0,830 / 0,958$ \\
\hline LOU & $0,821 / 0,846$ & $0,848 / 0,875$ & $0,881 / 0,912$ & $0,045 / 0,064$ \\
\hline Total & $0,852 / 0,865$ & $0,973 / 0,937$ & $1,146 / 1,201$ & $0,680 / 0,739$ \\
\hline
\end{tabular}

In the initial period, the greatest risk is $R_{b}$ downtime, about $80-90 \%$ of costs. The risk costs associated with the possible loss of customer's confidence $R_{p}$ have steadily been growing since the beginning of the operation. At the bus's mileage of about 55 thousand $\mathrm{km}$ for the $\mathrm{D}$ make the $R_{p}$ costs are beginning to dominate in the total costs and this trend it is maintained during the entire further period of operation. A similar situation takes place in the case of the I make, but the characteristic increase in the cost of losing the customer's confidence occurs at the mileage of approx. 70 thousand $\mathrm{km}$. The maximum share of the costs of risk of losing customer's confidence for the D make was $59.6 \%$, and for the I make it was $64.0 \%$. 


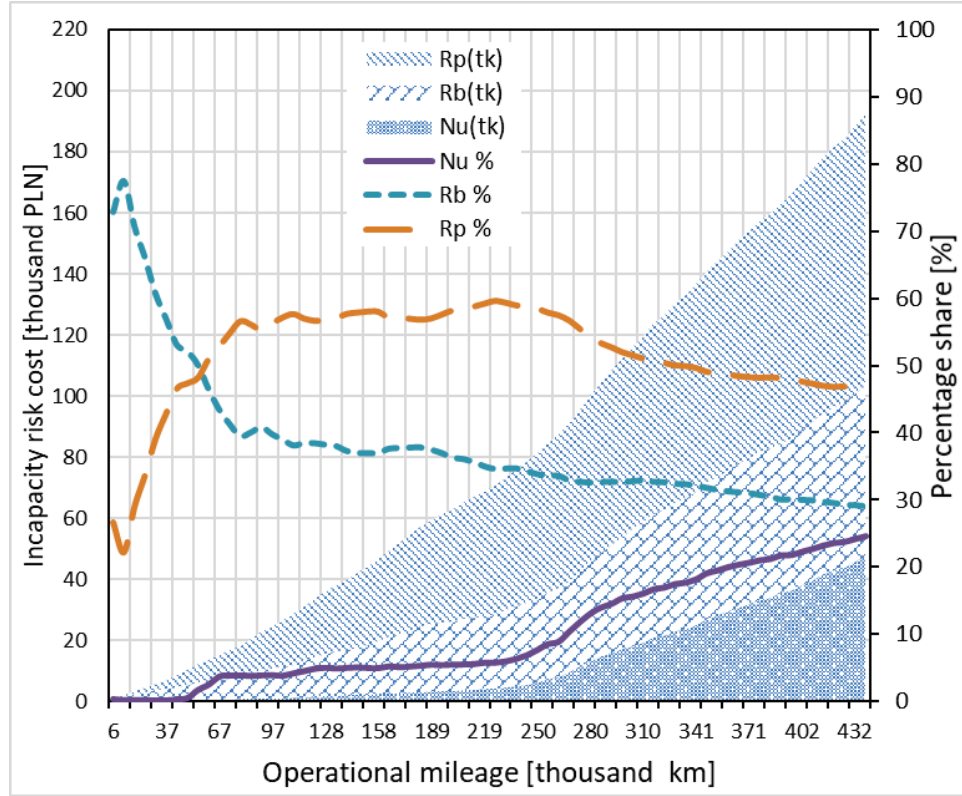

Fig. 3. Structure of the incapacity risk costs and percentage shares of the costs components for the D make

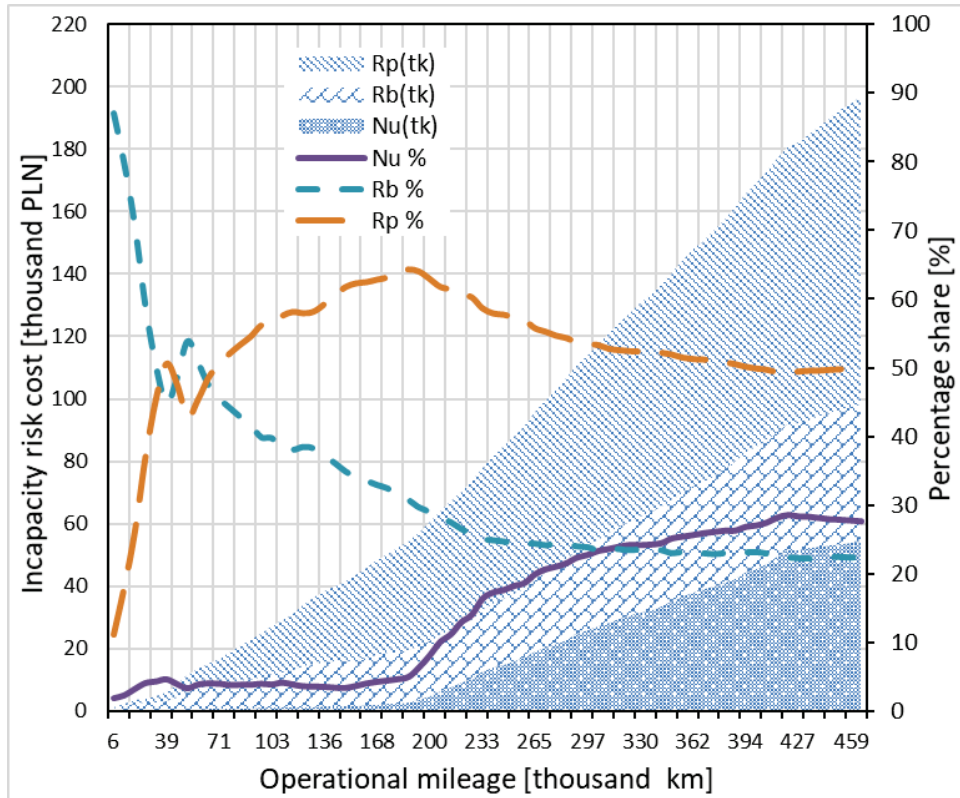

Fig. 4. Structure of the incapacity risk costs and percentage shares of the costs components for the I make 


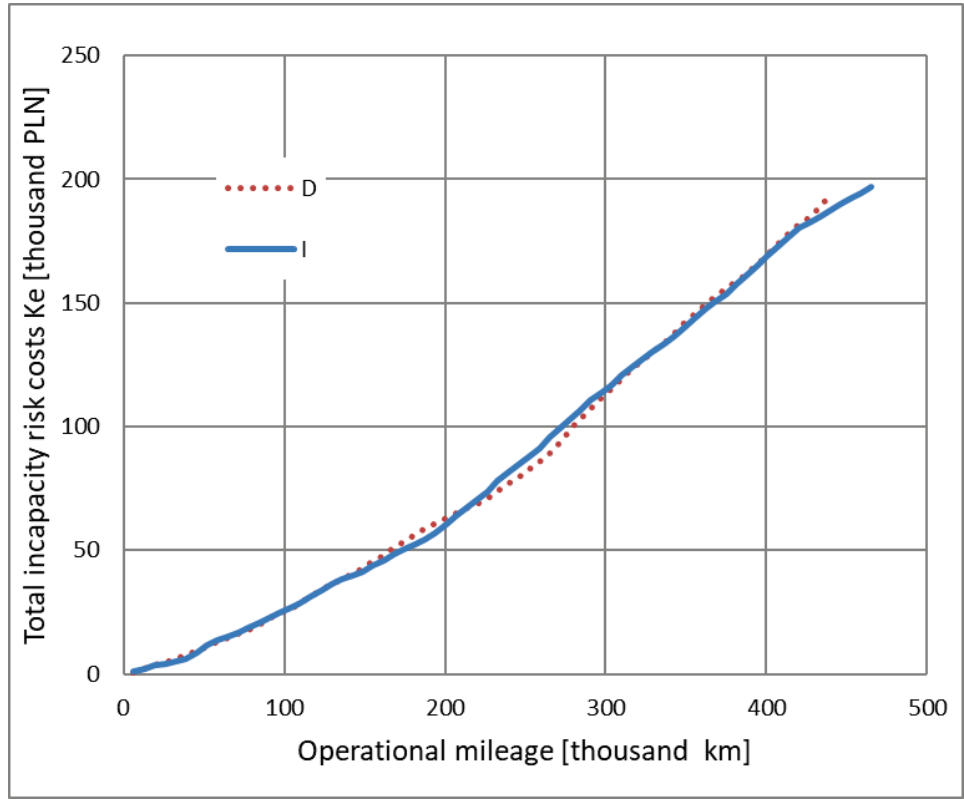

Fig. 5. Total costs of incapacity risk for both manufacturers of D and I buses

An important difference between the two makes is the moment when vehicles start to generate increased costs of unplanned repairs. This can be ascertained based on the analysis of the course of $N_{u}$ repair costs and the costs $R_{p}$ of the risk of losing trust. For the D make, this moment falls on the operating mileage of approx. 260 thousand $\mathrm{km}$, for the I make it is about $200,000 \mathrm{~km}$. The cumulated costs for both makes of vehicles in the period of operation are comparable (fig. 5). Vehicles of the $\mathrm{D}$ and I makes generate relatively low incidental repair costs in the FOU period (figs. 6, 7). At the end of the full operational usefulness period, it is $5.8 \%$ for the D make and $4.6 \%$ for the I one respectively. The share of downtime risk related costs also has a similar course for both bus makes and decreases with the increase in the operating time, reaching the share values of $30-35 \%$, while the costs of risk are different and amount to approx. 24 thousand. PLN for the D make and approx. 17,000 for I one. For the D make, costs of the risk of losing confidence at the end of the FOU period constitute about $60 \%$ of total costs, and in the case of the I make it is about $65 \%$. 


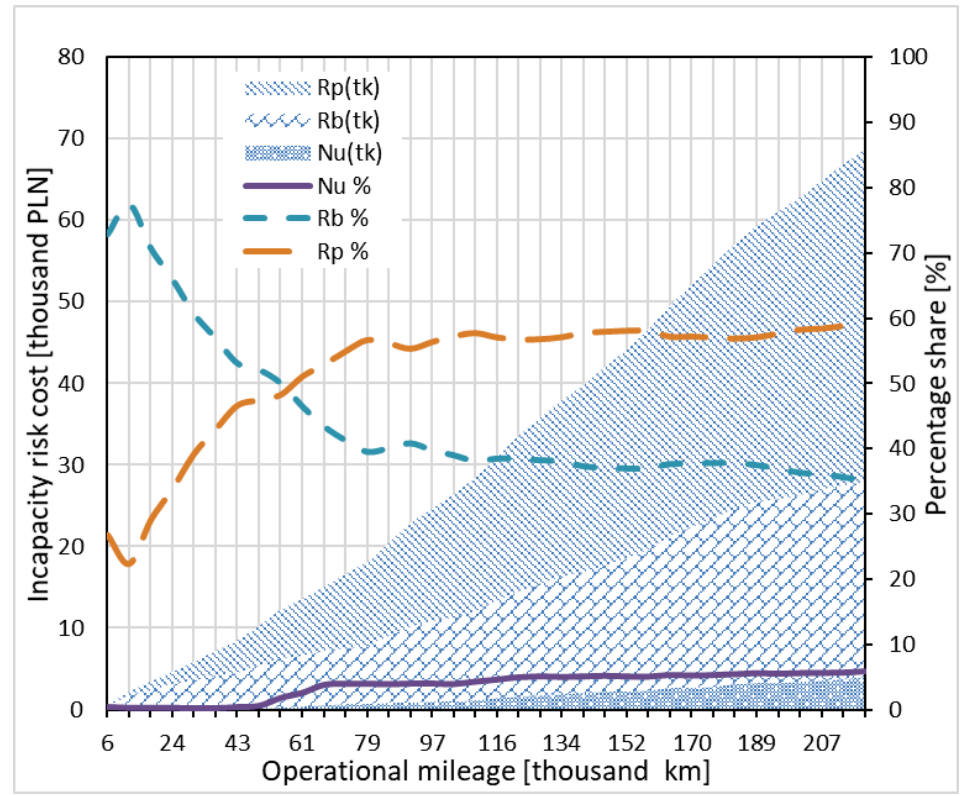

Fig. 6. Structure of the incapacity risk costs and percentage shares of the costs components for the D make in the FOU period

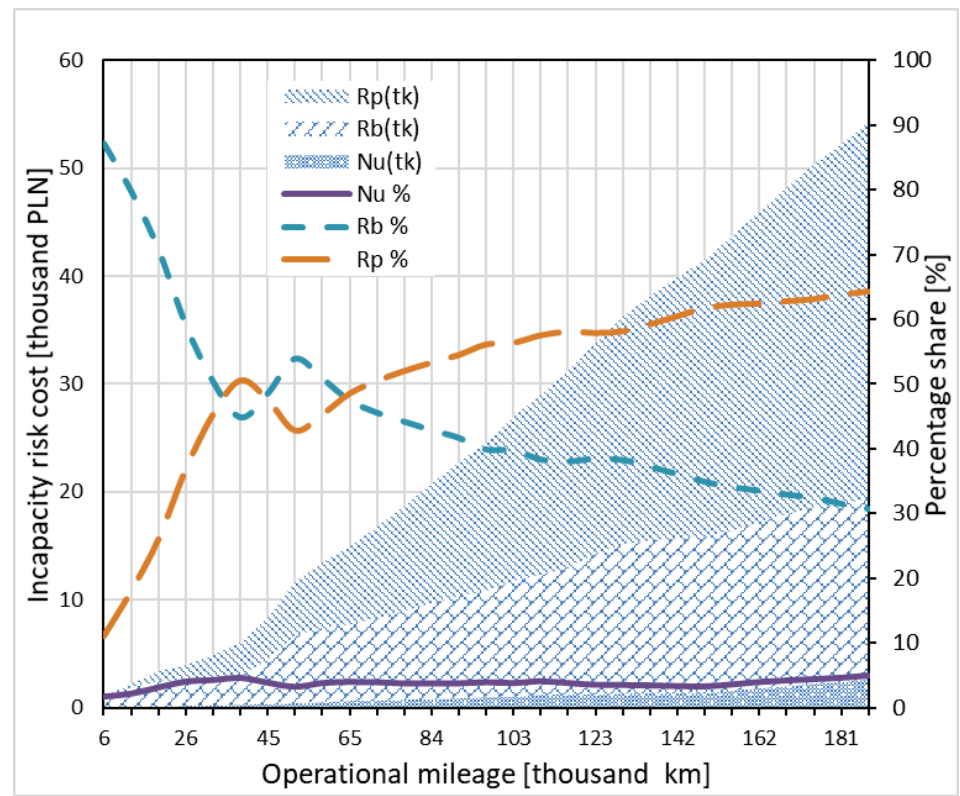

Fig. 7. Structure of the incapacity risk costs and percentage shares of the costs components for the I make in the FOU period 


\section{Discussion on the results}

The results of the operational efficiency calculations obtained allow to conclude that the highest efficiency of buses (over 1) occurs in the first period of 150 thousand $\mathrm{km}$ for both makes (fig. 1). The values of operational efficiency are comparable for both examined makes both in the warranty and post-warranty periods (fig. 2a). This may indicate a very similar bus life cycle design model used by both manufacturers. However, the difference in the purchase price of each bus 80 thousand PLN (table 1), should be noted. High reliability and thus high operational efficiency during the warranty period is particularly important from the manufacturer's point of view, because during this period the manufacturer covers the costs of repairs. However, regardless of the manufacturer, the user (transport company) is burdened with the costs of unplanned downtime and loss of customer confidence. The most favourable situation for the company would be a situation in which the warranty period would be matched to the reliability limit of the operating time. In most cases, however, it is economically unprofitable.

The presented paper introduces a new division of the predicted operational time into the period of full operational usefulness (FOU), determined by low costs of unplanned repairs while maintaining a high operational efficiency indicator and into the limited operational usefulness (LOU), in which vehicle's wear defects occur, generating the need for repairs.

The determined efficiency indicator in the FOU period for both vehicle makes indicates a difference of 0.281 . However, the difference in efficiency of both makes in the LOU period is only 0.028 .

The factor that distinguishes the presented model of operational efficiency assessment is the inclusion of risk costs due to the loss of customer confidence. As shown, these costs can have a significant share in the total costs.

\section{Conclusions}

1. An extended assessment of the expected operational efficiency of buses should include the costs of the risk of losing passengers (users) confidence. These costs are a significant component of the total costs of the bus reliability.

2. Characteristics of the course of individual components of vehicles' incapacity risk as a function of operating time is the basis for defining the boundary between the periods of their full operational usefulness (FOU) and limited operational usefulness (LOU). This can be used to determine the optimal time 
of their operation or to compare vehicle makes from the point of view of operational potential.

\section{References}

1. Andrzejczak K.: Metody prognozowania w modelu eksploatacyjnym środków transportu. Wydawnictwo Politechniki Poznańskiej, Poznań 2013.

2. Dmowski A.: Model oceny efektywności eksploatacyjnej samochodu ciężarowego w warunkach wynajmu długoterminowego przy uwzględnieniu wskaźników niezawodnościowych. Rozprawa doktorska, Instytut Lotnictwa, 2017.

3. Gawron H.: Rozwój aglomeracji miejskich i ich znaczenie dla rozwoju lokalnego rynku nieruchomości. Zarządzanie i Finanse, 4(12)/2014.

4. Kulińska E.: Model parametryzacji kosztów ryzyka w procesie transportu. Logistyka, 6/2013.

5. Michalski R., Wierzbicki S.: Comparative reliability tests of city transport busses. Eksploatacja i Niezawodność - Maintenance and Reliability, 4(32)/2006.

6. Niewczas A., Rymarz J., Dębicka E.: Stages of operating vehicles with respect to operational efficiency using city buses as an example. Eksploatacja i Niezawodność Maintenance and Reliability, 21(1)/2019, DOI 10.17531/ein.2019.1.3.

7. Niewczas A., Rymarz J., Pieniak D.: Porównawcza analiza niezawodności komunikacji miejskiej. Prace Naukowe Politechniki Warszawskiej, Transport, 101/2014.

8. Rymarz J., Badania efektywności eksploatacyjnej autobusów komunikacji miejskiej. Rozprawa doktorska, Politechnika Lubelska, Lublin 2015.

9. Zwierzchowska M.: Ocena jakości usług komunikacji miejskiej - dobór zmiennych do badania metodą delficką. Autobusy, 5/2018. 


\section{PROGNOZOWANIE KOSZTÓW RYZYKA NIEZDATNOŚCI AUTOBUSÓW MIEJSKICH}

\section{Wprowadzenie}

Wraz z rozwojem aglomeracji miejskich, rosną także wymagania i oczekiwania mieszkańców w stosunku do infrastruktury miasta. Rozwój ten prowadzi do wzrostu poziomu życia mieszkańców, lecz z drugiej strony do wzrostu kosztów utrzymania. Wypadkowym skutkiem tych zjawisk jest tzw. suburbanizacja, czyli migracja ludności z miast na tereny podmiejskie [3]. Prowadzi to do wyodrębnienia strefy „ścisłego" miasta (centrum), gdzie skoncentrowane są siedziby zakładów pracy, i strefy podmiejskiej, gdzie zlokalizowane są osiedla mieszkalne. W takim modelu urbanizacji duże znaczenie ma funkcjonowanie dobrze skoordynowanego transportu publicznego, spełniającego wysokie wymagania jakościowe i ilościowe podróżujących. Pod względem jakościowym wymagania te rozumiane są jako duża niezawodność środków transportowych, punktualność i bezpieczeństwo przewozów. Pod względem ilościowym to przede wszystkim właściwa liczba środków transportowych, adekwatna do rozbudowanej sieci komunikacyjnej.

W sytuacji dynamicznego rozwoju dużych aglomeracji miejskich, wyzwanie stawia się wobec miejskich przedsiębiorstw transportowych, oczekując zapewnienia wysokiej jakości przewozów przy akceptowalnych kosztach inwestycyjnych i eksploatacyjnych. Jakość realizowanych przewozów jest silnie uzależniona od niezawodności użytkowanych pojazdów. Wysoki poziom niezawodności warunkuje wysoką efektywność eksploatacyjną oraz terminowość przewozów i utrzymanie stabilnego zaufania klientów - pasażerów.

Zapewnienie wysokiej niezawodności pojazdów i jej utrzymanie w zaplanowanym okresie eksploatacji jest trudnym zadaniem. Dlatego każdy system transportu miejskiego powinien uwzględniać zabezpieczenia ciagłości działania związane z ryzykiem niezdatności posiadanej floty pojazdów. Ryzyko to jest generowane już na etapie zakupu środków transportowych. Jest ono również podstawą prognozowania kosztów eksploatacji [1, 4, 5].

W niniejszym artykule, wykorzystując autorski model oceny efektywności eksploatacyjnej oraz bazę danych o uszkodzeniach i naprawach incydentalnych 
z okresu sześciu lat w odniesieniu do grupy autobusów miejskich dwóch marek krajowej i importowanej, określono przewidywane koszty ryzyka ich niezdatności. W obliczeniach poza kosztami napraw nieplanowanych, uwzględniono również koszty związane $\mathrm{z}$ utraconym przychodem $\mathrm{w}$ czasie wymuszonego przestoju autobusów, a także koszty związane z prawdopodobnym ryzykiem utraty zaufania klienta.

\section{Przebieg badań}

W badaniach wykorzystano dane zebrane w wybranym przedsiębiorstwie komunikacji miejskiej działającym na terenie jednego z większych miast w Polsce. W celach porównawczych skupiono się na autobusach dwóch producentów, które na potrzeby niniejszego artykułu zostały oznaczone następująco: D - producent krajowy, I - producent zagraniczny. Aby spełnić warunki jednorodności próby statystycznej, do badań wykorzystano pojazdy pochodzące $\mathrm{z}$ jednej partii produkcyjnej każdej marki. Autobusy były eksploatowane w tych samych warunkach drogowych i klimatycznych. Próbki autobusów w liczbie 20 marki D i $22 \mathrm{w}$ przypadku marki I były wprowadzone do eksploatacji w zbliżonym czasie kalendarzowym. Okres obserwacji wynosił 72 miesiące (6 lat). W tym czasie autobusy realizowały regularne przewozy pasażerów, obsługując rotacyjnie rozkładowe linie komunikacji miejskiej [8].

W tabeli 1 zamieszczono wskaźniki techniczno-eksploatacyjne autobusów obu marek, a w tabeli 2 przedstawiono zbiorcze wskaźniki intensywności użytkowania. Przyjęto, zgodnie z obowiązującymi regulacjami prawnymi, że roczna amortyzacja pojazdów wynosi $10 \%$ ceny zakupu autobusu i jest stała przez cały okres użytkowania.

Tabela 1

Podstawowe wskaźniki techniczno-eksploatacyjne autobusów

\begin{tabular}{|l|l|l||}
\hline \hline Wskaźnik & D & I \\
\hline Charakterystyka ogólna & \multicolumn{1}{|l|}{ dwuosiowy, jednopokładowy, niskopodłogowy } \\
\hline Kategoria homologacyjna & M3 \\
\hline Klasa & I (miejski), MAXI (pojazdy o długości 10,5-13 m) \\
\hline Liczba miejsc siedzących & 29 & 27 \\
\hline Liczba miejsc stojących & 74 & 78 \\
\hline Rodzaj silnika & zapłon samoczynny & \multicolumn{2}{|l|}{} \\
\hline Pojemność silnika $\left[\mathrm{cm}^{3}\right]$ & 9186 & 7201 \\
\hline
\end{tabular}




\begin{tabular}{|l|l|l||}
\hline Moc maks. silnika [kW] & 188 & 210 \\
\hline Masa własna [kg] & 10900 & 10860 \\
\hline Dopuszczalna masa całkowita [kg] & 18000 & 830 \\
\hline Koszt zakupu [tys. zł] & 750 & \multicolumn{2}{|l|}{} \\
\hline
\end{tabular}

Tabela 2

\section{Wskaźniki intensywności użytkowania [8]}

\begin{tabular}{|l|l|l|}
\hline Wskaźnik & D & I \\
\hline Liczność próby [szt.] & 20 & 22 \\
\hline Czas badania n [msc.] & 72 & \multicolumn{2}{|l|}{} \\
\hline $\begin{array}{l}\text { Średni przebieg w okresie } \\
72 \text { msc. [tys. km] }\end{array}$ & 438,30 & 417,94 \\
\hline Średni przebieg miesięczny [tys. km] & 6,09 & 6,46 \\
\hline Amortyzacja roczna [tys. zł] & 75 & 83 \\
\hline Amortyzacja miesięczna [tys. zł] & 6,25 & 6,92 \\
\hline
\end{tabular}

Do obliczeń efektywności eksploatacyjnej wykorzystano autorską modyfikację modelu efektywności eksploatacyjnej zaprezentowanego w pracy [2]. Równanie opisujące udoskonalony w niniejszej pracy model wyrażone jest wzorem:

$$
W_{e}=\frac{1}{\left(\frac{N_{u}}{A_{z}}\right)+\left(1-K_{g}\right)+F\left(t_{k}\right)}
$$

gdzie:

$N_{u} \quad$ - skumulowany koszt napraw incydentalnych w przedziale czasu $\left(0, t_{k}\right)$,

$A_{z} \quad-$ kwota amortyzacji do chwili $t_{k}$,

$K_{g} \quad$ - współczynnik gotowości technicznej w $k$-tym przedziale użytkowania,

$F\left(t_{k}\right)$ - dystrybuanta rozkładu Weibulla czasu do pierwszego uszkodzenia,

$t_{k} \quad-$ kres górny $k$-tego przedziału czasu użytkowania ( $k$-tego przedziału przebiegu).

Model zakłada zrównoważenie przychodu progowego (minimalnego) i kosztów amortyzacji pojazdu.

Dystrybuanta rozkładu Weibulla przyjętego jako model rozkładu czasu do pierwszego uszkodzenia opisana jest wzorem: 


$$
F\left(t_{k}\right)=1-e^{-\left(\frac{t_{k}}{a}\right)^{b}}
$$

gdzie:

$a$ - parametr skali,

$b$ - parametr kształtu.

Parametry skali i kształtu obliczono na podstawie rejestru uszkodzeń badanych autobusów marki D i marki I. Wyniki obliczeń podano w tabeli 3.

Tabela 3

\section{Parametry rozkładu trwałości badanych autobusów [7]}

\begin{tabular}{|l|l|l|}
\hline Producent & Parametr skali $\boldsymbol{a}$ & Parametr ksztaltu $\boldsymbol{b}$ \\
\hline D & $87,9 \times 10^{3}$ & 0,955 \\
\hline I & $80,5 \times 10^{3}$ & 0,819 \\
\hline
\end{tabular}

Przedstawione powyżej równanie wskaźnika efektywności eksploatacyjnej (1) pozwala na określenie kosztów ryzyka niezdatności, którego wzór ogólny określony jest następująco:

$$
K_{e}=N_{u}+R_{b}+R_{p}
$$

Składniki we wzorze (3) wyrażają koszty ryzyka związane z utrzymaniem zdatności pojazdu spowodowane nieplanowanymi naprawami $-N_{u}$, kosztami ryzyka związanymi $\mathrm{z}$ utratą przychodów podczas przestojów pojazdu w okresie eksploatacji $t_{k}-R_{b}$, kosztami ryzyka utraty zaufania klienta - pasażera spowodowane niezdatnością pojazdu $-R_{p}$. Forma rozwinięta równania (3) wyraża się wzorem:

$$
K_{e}=\sum_{k=1}^{n} N_{u}\left(t_{k}\right)+\sum_{k=1}^{n}\left[\Delta A_{z}\left(1-K_{g}\left(t_{k}\right)\right)\right]+A_{z} * 0,2 F\left(t_{k}\right)
$$

gdzie:

$N_{u}\left(t_{k}\right)$ - koszty napraw nieplanowanych w $k$-tym przedziale przebiegu,

$\Delta A_{z} \quad$ - kwota amortyzacji w przeliczeniu na średni miesięczny przebieg autobusu,

$K_{g}\left(t_{k}\right)$ - współczynnik gotowości technicznej w $k$-tym przedziale przebiegu.

$\mathrm{W}$ modelu zrezygnowano $\mathrm{z}$ uwzględniania kosztów planowanych. W szczególności nie uwzględniono kosztów: paliwa, mocznika (Adblue), planowanych obsług technicznych, osobowych, ubezpieczeń, podatków, pozostałych kosztów materiałowych. Ryzyko utraty zaufania wyrażone jako ostatni 
składnik sumy w równaniach (3) i (4) zawiera dodatkowy współczynnik 0,2 będący założeniem, że jedynie co piąty pasażer (20\%) zrezygnuje z transportu publicznego na skutek powtarzalnej niezdatności autobusów i wynikającej stąd nieterminowości przewozów [9].

\section{Wyniki badań}

Wskaźnik efektywności $W_{e}$ obliczony z równania (1) w zależności od przebiegu eksploatacyjnego przedstawiono na rys. 1. Obliczenia wykonano w odniesieniu do średniego miesięcznego przebiegu. Na wykresie można zauważyć progresywne obniżanie się wskaźnika efektywności wraz z wrastającym czasem użytkowania dla autobusów obu marek. Rozpatrując cały okres obserwacji, średnia wartość wskaźnika dla marki D wynosi 1,181, a dla marki I kształtuje się na poziomie 1,228 .

W celu bardziej dokładnego porównania marek pojazdów miedzy sobą przy uwzględnieniu ich zużywania eksploatacyjnego, podzielono całkowity okres obserwacji na dwa szczegółowe okresy. W pierwszej kolejności na okres gwarancyjny (0-2 lat) i okres pogwarancyjny (3-6 lat) (rys. 2). Wartości wskaźnika efektywności $\mathrm{w}$ obu tych okresach są porównywane dla obu marek, w szczególności w okresie pogwarancyjnym. Istotne jest, że po upływie okresu gwarancji średnia wartość wskaźnika efektywności w pozostałym czasie eksploatacji jest dwa razy mniejsza. Szczegółowa analiza kosztów napraw nieplanowanych pozwala stwierdzić, że bardziej odpowiednim podziałem jest okres pełnej przydatności eksploatacyjnej (w skrócie PPE) i ograniczonej przydatności eksploatacyjnej (OPE) [6]. W tab. 4 przedstawiono zakresy czasu użytkowania $\mathrm{w}$ ujęciu miesięcznym, na podstawie których określono granicę okresów PPE i OPE dla obu marek. 


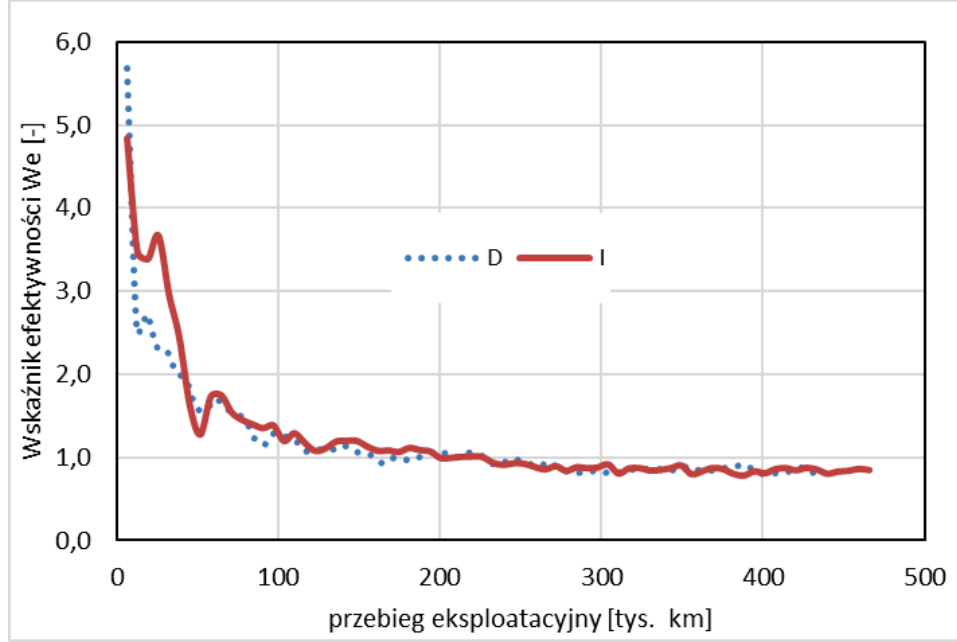

Rys. 1. Wskaźnik efektywności eksploatacyjnej $W_{e} \mathrm{w}$ funkcji przebiegu eksploatacyjnego dla całkowitego okresu obserwacji

Dla okresów PPE i OPE przeprowadzono statystyczne porównanie wartości średnich z wykorzystaniem metody analizy wariancji. Wykorzystano testy Shapiro-Wilka i jednoczynnikowej analizy wariancji. Statystyki opisowe przedstawiono w tab. 5.

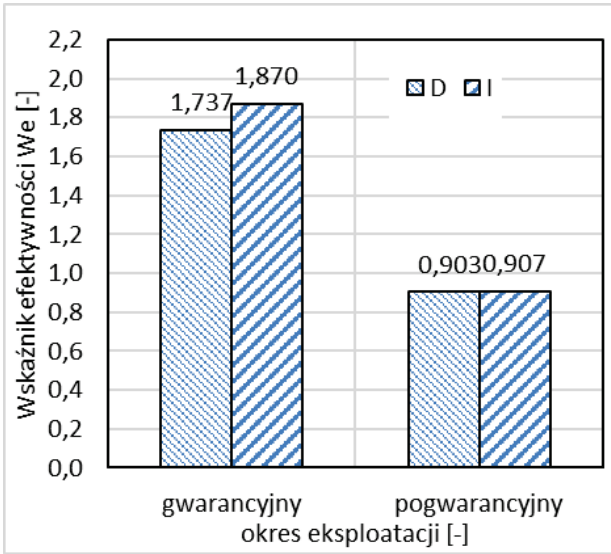

a)

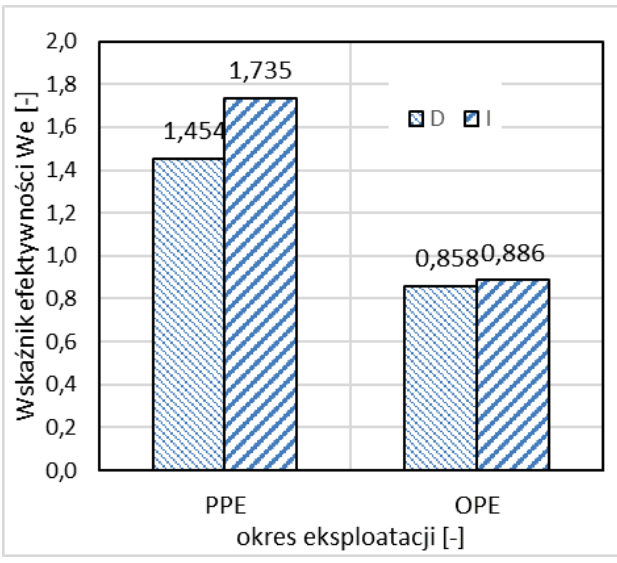

b)

Rys. 2. Średnia wartość wskaźnika efektywności eksploatacyjnej w okresie gwarancyjnym i pogwarancyjnym (a) oraz pełnej przydatności eksploatacyjnej i ograniczonej przydatności eksploatacyjnej (b) 


\section{Tabela 4}

\section{Podzial na okres PPE i OPE}

\begin{tabular}{||l|l|l|}
\hline Okres & D & I \\
\hline PPE $[\mathrm{msc}]$ & $0-36$ & $0-29$ \\
\hline OPE $[\mathrm{msc}]$ & $37-72$ & $30-72$ \\
\hline
\end{tabular}

Strukturę kosztów ryzyka obliczonego według równania (5) dla marki D i marki I przedstawiono na rys. 3 i 4 . Dla zwiększenia czytelności naniesiono dodatkowo linie $\mathrm{z}$ osią pomocniczą określające procentowy udział kosztów. W początkowym okresie największe ryzyko stanowią przestoje $R_{b}$, ok. $80-90 \%$ kosztów. Koszty ryzyka związane z możliwą utratą klienta $R_{p}$ sukcesywnie rosną od chwili rozpoczęcia eksploatacji. Przy przebiegu autobusu ok. 55 tys. km dla marki D koszty $R_{p}$ zaczynają dominować w kosztach całkowitych i ten trend jest utrzymywany w czasie całego dalszego okresu eksploatacji. Podobna sytuacja ma miejsce w przypadku marki I, lecz charakterystyczny wzrost kosztu utraty zaufania klienta następuje przy przebiegu ok. 70 tys. km. Maksymalny udział kosztów ryzyka utraty zaufania klienta dla marki D wyniósł 59,6 \%, a dla marki I 64\%.

\section{Tabela 5}

Wartości statystyk opisowych efektywności eksploatacyjnej dla obu marek w różnych okresach użytkowania autobusów

\begin{tabular}{||l|l|l|l|l||}
\hline \multirow{2}{*}{ Okres } & \multicolumn{4}{|c||}{$\mathrm{D} / \mathrm{I}$} \\
\cline { 2 - 6 } & kwartyl dolny & mediana & kwartyl górny & $\begin{array}{c}\text { odchylenie } \\
\text { stand. }\end{array}$ \\
\hline gwarancyjny & $1,151 / 1,201$ & $1,491 / 1,394$ & $1,960 / 1,923$ & $0,954 / 1,002$ \\
\hline pogwarancyjny & $0,836 / 0,85$ & $0,880 / 0,877$ & $0,972 / 0,936$ & $0,081 / 0,087$ \\
\hline PPE & $0,823 / 1,132$ & $1,101 / 1,294$ & $0,307 / 1,731$ & $0,830 / 0,958$ \\
\hline OPE & $0,821 / 0,846$ & $0,848 / 0,875$ & $0,881 / 0,912$ & $0,045 / 0,064$ \\
\hline całkowity & $0,852 / 0,865$ & $0,973 / 0,937$ & $1,146 / 1,201$ & $0,680 / 0,739$ \\
\hline \hline
\end{tabular}




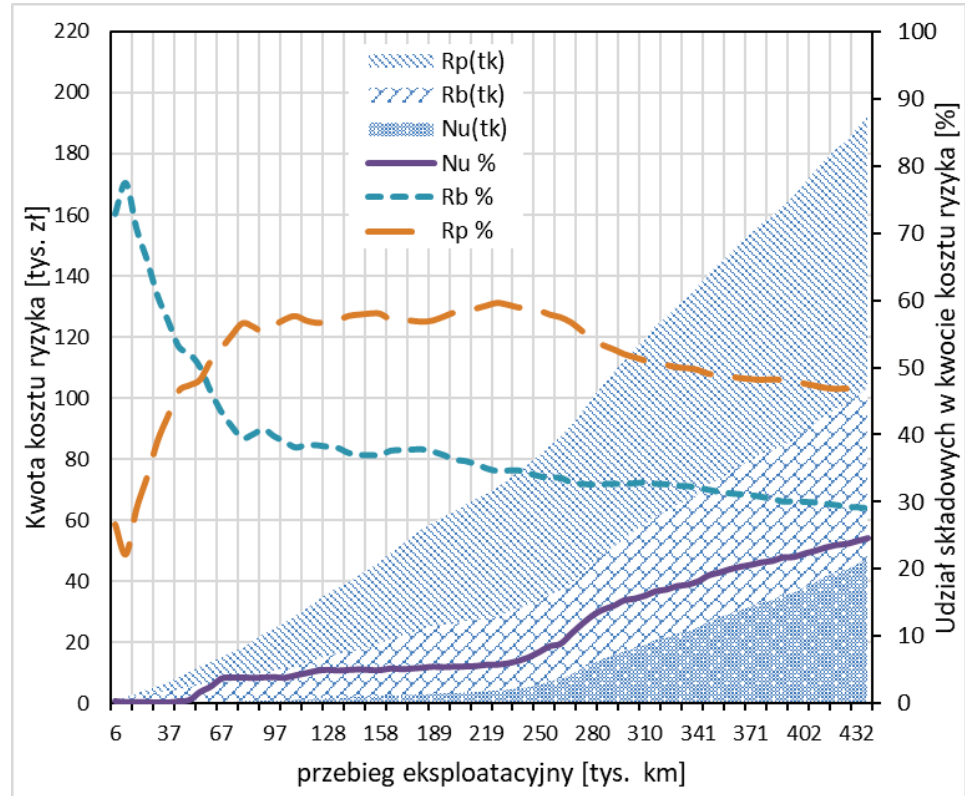

Rys. 3. Struktura kosztów ryzyka niezdatności i udziały procentowe składowych kosztów dla marki D

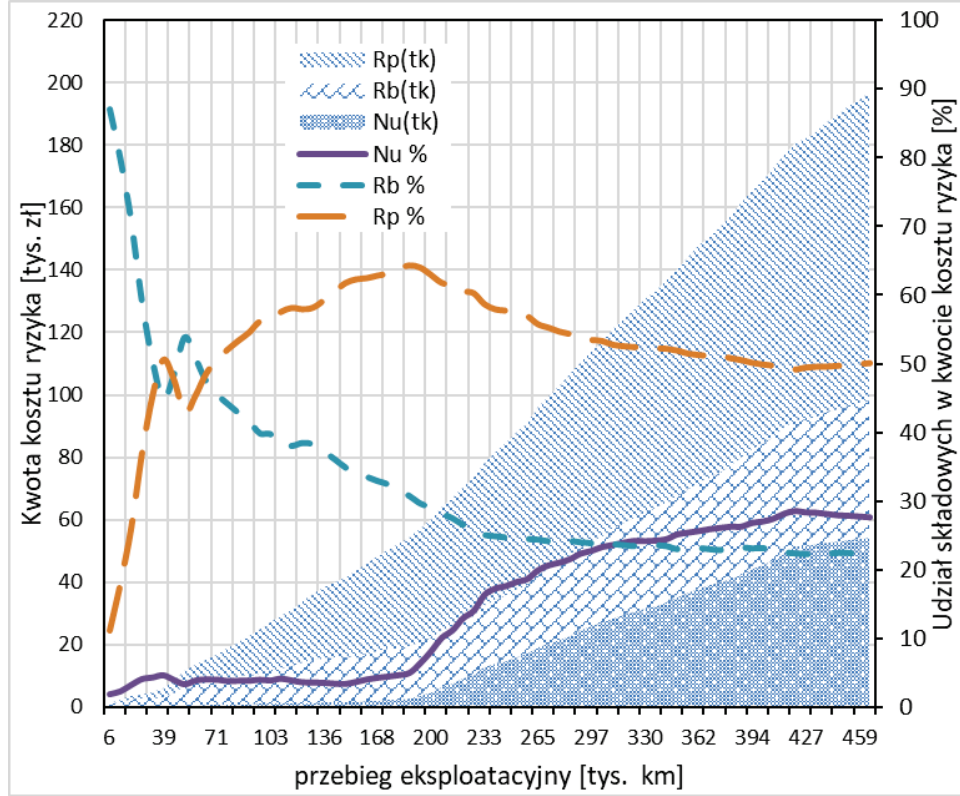

Rys. 4. Struktura kosztów ryzyka niezdatności i udziały procentowe składowych kosztów dla marki I 


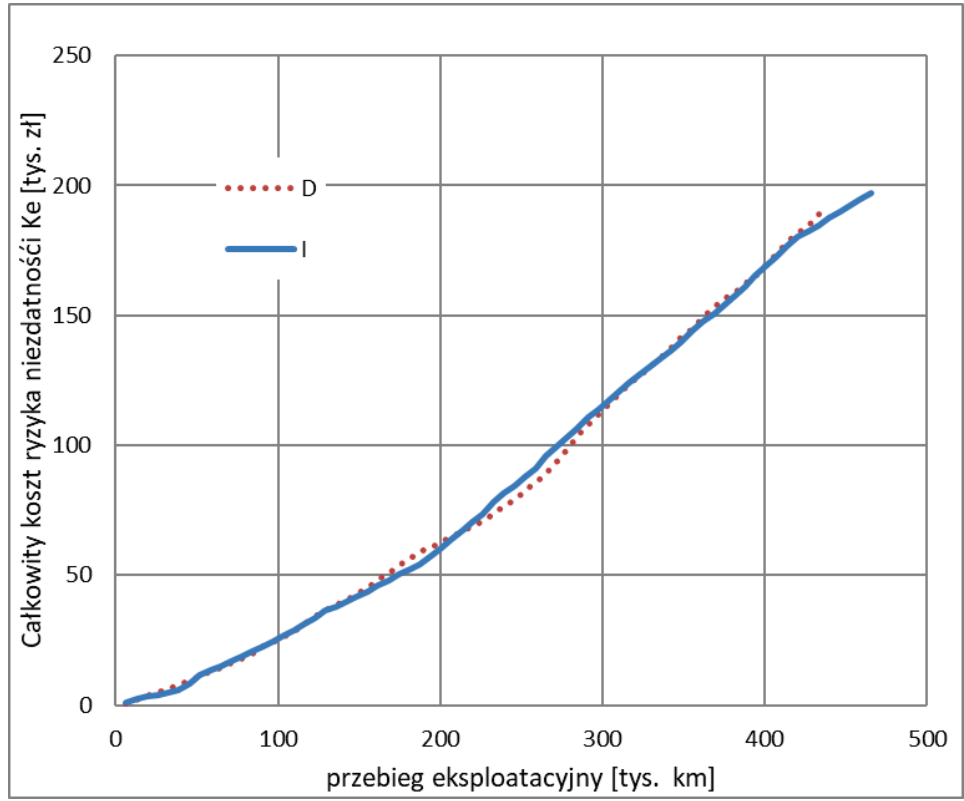

Rys. 5. Całkowite koszty ryzyka niezdatności dla obu producentów autobusów D i I

Istotną różnicą pomiędzy obiema markami jest chwila kiedy pojazdy zaczynają generować zwiększone koszty napraw nieplanowanych. Można to stwierdzić na podstawie analizy przebiegu kosztów napraw $N_{u}$ i kosztów ryzyka utraty zaufania $R_{p}$. Dla marki D chwila ta przypada na przebieg eksploatacyjny ok. 260 tys. km, dla marki I jest to około 200 tys. km. Skumulowane koszty dla obu marek pojazdów w okresie eksploatacji są porównywalne (rys. 5). Pojazdy marki D i I w okresie PPE generują stosunkowo niskie koszty napraw incydentalnych (rys. 6, 7). Na koniec okresu pełnej przydatności eksploatacyjnej jest to odpowiednio 5,8\% dla marki D i 4,6\% dla I. Udział kosztów ryzyka związanego z przestojami również ma zbliżony przebieg dla obu marek autobusów i maleje wraz ze wzrostem czasu eksploatacyjnego, osiagając wartości udziału na poziomie 30-35\%, kwoty kosztów ryzyka są różne i wynoszą ok. 24 tys. zł dla marki D i ok. 17 tys. zł dla I. Dla marki D koszty ryzyka utraty zaufania pod koniec okresu PPE stanowią ok. 60\% kosztów całkowitych, a w przypadku marki I jest to ok. $65 \%$. 


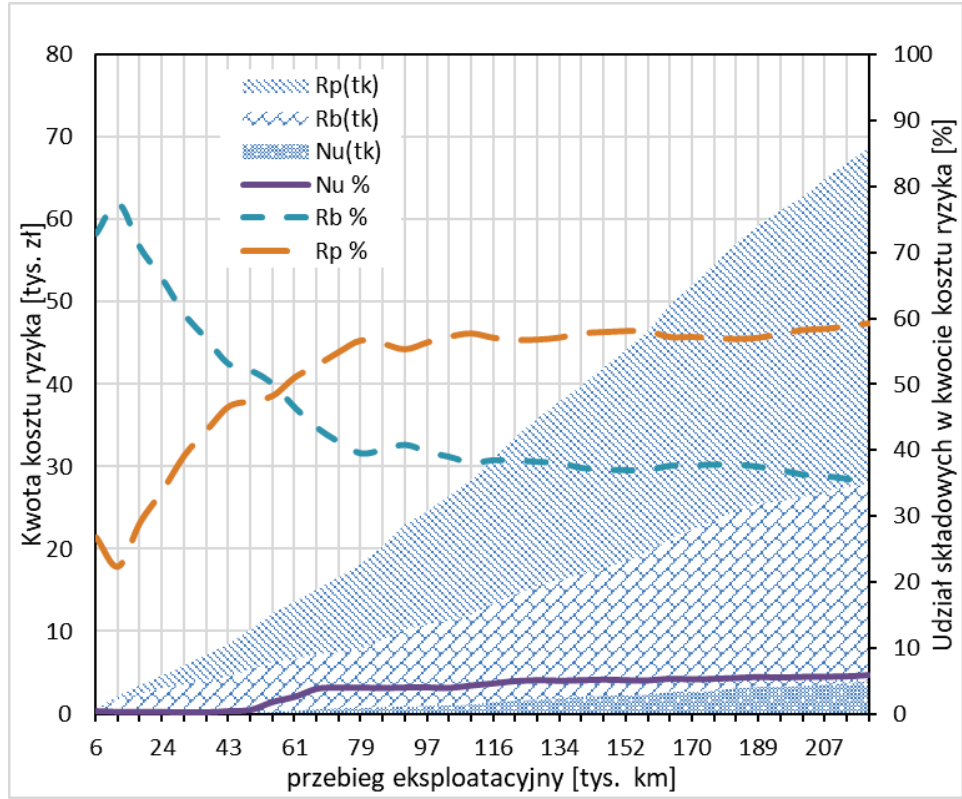

Rys. 6. Struktura kosztów ryzyka niezdatności i udziały procentowe składowych kosztów dla marki D w okresie PPE

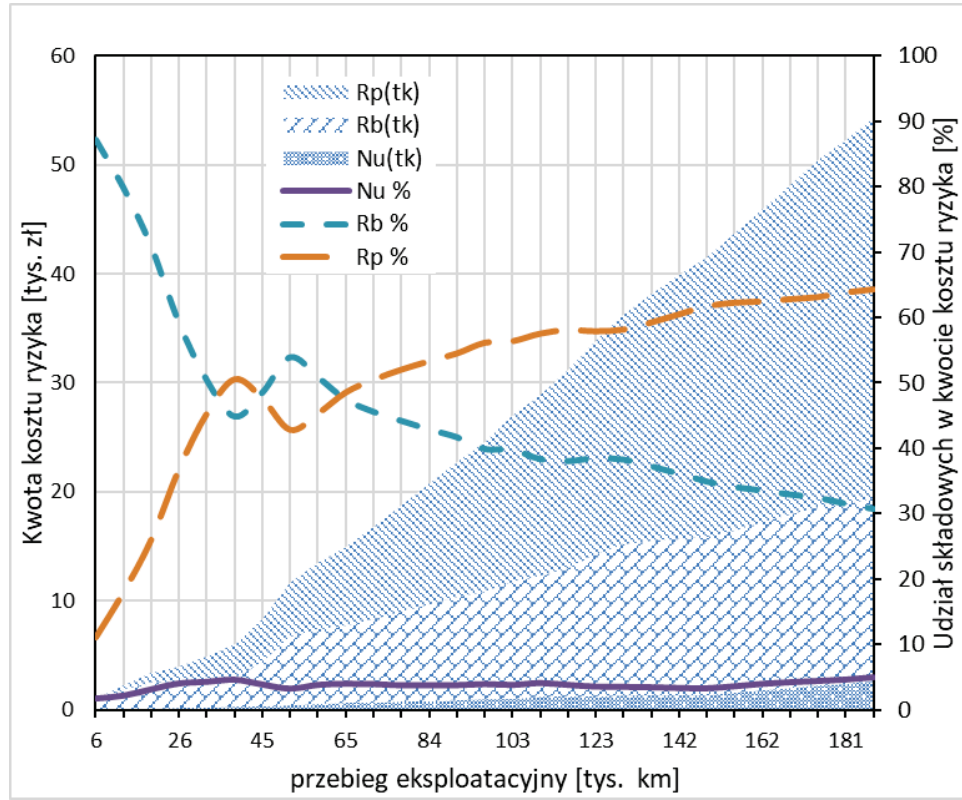

Rys. 7. Struktura kosztów ryzyka niezdatności i udziały procentowe składowych kosztów dla marki I w okresie PPE 


\section{Dyskusja wyników}

Otrzymane wyniki obliczeń efektywności eksploatacyjnej pozwalają stwierdzić, że najwyższa efektywność autobusów (powyżej jedności) zachodzi w pierwszym okresie 150 tys. km dla obu marek (rys. 1). Wartości efektywności eksploatacyjnej są porównywalne dla obu badanych marek zarówno w okresie gwarancyjnym, jak i pogwarancyjnym (rys. 2a). Może to świadczyć o bardzo zbliżonym modelu projektowania cyklu ,życia” autobusów stosowanym przez obu producentów. Należy jednak zwrócić uwagę na różnicę w cenie zakupu autobusów - 80 tys. zł (tab. 1). Wysoka niezawodność, a tym samym duża efektywność eksploatacyjna w okresie gwarancyjnym jest szczególnie ważna z punktu widzenia producenta, ponieważ w tym okresie producent pokrywa koszty napraw. Jednak niezależnie od producenta użytkownik (przedsiębiorstwo transportowe) jest obciążony kosztami ryzyka nieplanowanych przestojów i utraty zaufania klienta. Najkorzystniejsza dla przedsiębiorstwa byłaby sytuacja, w której okres gwarancji byłby dopasowany do niezawodnościowej granicy czasu eksploatacji. W większości przypadków jest to jednak ekonomicznie nieopłacalne. W prezentowanej pracy wprowadzono nowy podział prognozowanego czasu eksploatacji na okres pełnej przydatności eksploatacyjnej (PPE), determinowany przez niskie koszty napraw nieplanowanych przy jednoczesnym zachowaniu wysokiego wskaźnika efektywności eksploatacyjnej oraz okres ograniczonej przydatności eksploatacyjnej (OPE), w którym występują uszkodzenia zużyciowe pojazdu, generujące potrzebę napraw.

Wyznaczony wskaźnik efektywności w okresie PPE dla obu marek pojazdów wskazuje na różnice wynoszącą 0,281 . Natomiast różnica efektywności obu marek w okresie OPE wynosi tylko 0,028 .

Czynnikiem wyróżniającym przedstawiony model oceny efektywności eksploatacyjnej jest uwzględnienie kosztów ryzyka z tytułu utraty zaufania klienta. Jak wykazano, koszty te mogą mieć znaczący udział kosztach całkowitych.

\section{Wnioski}

1. Rozszerzona ocena przewidywanej efektywności eksploatacyjnej autobusów powinna obejmować koszty ryzyka utraty zaufania pasażerów (użytkowników). Koszty te stanowią znaczący składnik całkowitych kosztów niezawodności autobusów.

2. Charakterystyka przebiegu poszczególnych składników ryzyka niezdatności pojazdów w funkcji czasu użytkowania jest podstawą do określenia granicy 
pomiędzy okresami ich pełnej przydatności eksploatacyjnej (PPE) i ograniczonej przydatności eksploatacyjnej (OPE). Może to być wykorzystane do ustalenia optymalnego czasu ich użytkowania lub do porównywania marek pojazdów z punktu widzenia potencjału eksploatacyjnego.

\section{Literatura}

1. Andrzejczak K.: Metody prognozowania w modelu eksploatacyjnym środków transportu. Wydawnictwo Politechniki Poznańskiej, Poznań 2013.

2. Dmowski A.: Model oceny efektywności eksploatacyjnej samochodu ciężarowego w warunkach wynajmu długoterminowego przy uwzględnieniu wskaźników niezawodnościowych. Rozprawa doktorska, Instytut Lotnictwa, 2017.

3. Gawron H.: Rozwój aglomeracji miejskich i ich znaczenie dla rozwoju lokalnego rynku nieruchomości. Zarządzanie i Finanse, 4(12)/2014.

4. Kulińska E.: Model parametryzacji kosztów ryzyka w procesie transportu. Logistyka, 6/2013.

5. Michalski R., Wierzbicki S.: Badania porównawcze niezawodności autobusów komunikacji miejskiej. Eksploatacja i Niezawodność - Maintenance and Reliability, $4(32) / 2006$.

6. Niewczas A., Rymarz J., Dębicka E.: Etapy użytkowania pojazdów ze względu na efektywność eksploatacyjną na przykładzie autobusów miejskich. Eksploatacja i Niezawodność - Maintenance and Reliability, 21(1)/2019, DOI 10.17531/ein.2019.1.3.

7. Niewczas A., Rymarz J., Pieniak D.: Porównawcza analiza niezawodności komunikacji miejskiej. Prace Naukowe Politechniki Warszawskiej, Transport, $101 / 2014$.

8. Rymarz J., Badania efektywności eksploatacyjnej autobusów komunikacji miejskiej. Rozprawa doktorska, Politechnika Lubelska, Lublin 2015.

9. Zwierzchowska M.: Ocena jakości usług komunikacji miejskiej - dobór zmiennych do badania metodą delficką. Autobusy, 5/2018. 